\title{
Performance Evaluation of Sewage Treatment Plants in Lucknow City
}

Mansi Tripathi and S. K. Singal

Abstract: The present study was conducted to evaluate the performance of existing sewage treatment plants (STPs) in Lucknow City of India. Currently, two STPs are operating in Lucknow, i.e., UASB reactor and FAB reactor, with total operating capacity of 345MLD and 56MLD, respectively. Since, the wastewater get mix with the domestic effluent while directing towards the STPs, therefore, the concentration of BOD is relatively very low, and hence the amount of biogas production by the UASB reactor is also reduced than its design value. Two approaches, evaluating the treatability performance and Life-Cycle Assessment (LCA) have been used to determine the plants efficiencies. All the results have been interpreted graphically. The results of this study conclude that the UASB reactor is better than the FAB, however in terms of LCA the FAB seems to be more reliable.

Key words: Sewage treatment, life cycle analysis, pollution, UASB, FAB, land cost, influent, effluent, Lucknow City, India

\section{Introduction}

The overall water management objectives of of pollutants and to protect and preserve our natural water resources. Protection of human health from the pathogenic organisms present in sewage prior to the treated effluent being discharged to the receiving water bodies are of specific concern. The purpose of sewage treatment is to remove the organic and inorganic solids where the organic solids are decomposed by microorganisms and inorganic solids due to sedimentation. As the rivers are the major sources of drinking water needs, the treatment of sewage becomes necessary before discharging into the rivers.

Lucknow city is the capital of Uttar Pradesh state in India. It is situated on the banks of the river Gomti, and has a current population of about 2.803 million. This study is concentrated in the area of Lucknow city with latitude-longitude extent of $26.85^{\circ} \mathrm{N}$ and $80.92^{\circ}$ E. According to IS: $1171-1971$ an average domestic consumption of water under normal conditions is 135 lit/ cap/day in India (Chavan 2007). Hence for a population of 2.803 million, by considering losses in the treatment plant and distribution system as $15 \%$ and $5 \%$ for non domestic supply, wastewater treatment plants with a total capacity of 454.086 MLD are required. However, as per the predicted population in the year 2010, Lucknow should have faced a wastewater generation of just 344 MLD. In the current sewerage scheme of the city, there are four separate Sewerage Districts each with its own commissioned or proposed treatment plant as shown in Table 1.

\begin{tabular}{|l|l|l|l|l|}
\hline $\begin{array}{c}\text { S. } \\
\text { No. }\end{array}$ & \multicolumn{1}{|c|}{ Areas covered } & $\begin{array}{c}\text { Name of } \\
\text { STP }\end{array}$ & $\begin{array}{c}\text { Capacity } \\
\text { of STP } \\
\text { (MLD) }\end{array}$ & \multicolumn{1}{|c|}{$\begin{array}{c}\text { Proposed/ } \\
\text { Running }\end{array}$} \\
\hline 1 & $\begin{array}{l}\text { Chowk, Hardoi Road, } \\
\text { Cambell Road, Dubagga }\end{array}$ & Daulatganj & 56 & Running \\
\hline 2 & Amausi and Sarojini Nagar & Khwajapur & 108 & Proposed for 2040 \\
\hline 3 & Total Trans Gomti side & Bharwara & 345 & Running \\
\hline 4 & Remaining C is Gomti side & Mastemau & 270 & Proposed for 2040 \\
\hline
\end{tabular}

Table 1. Sewerage Districts in Lucknow City.

\section{Technologies Used For Sewage Treatment}

Upflow Anaerobic Sludge Blanket (UASB) and Fluidized Aerobic Bioreactor (FAB) are the two technologies currently being used to treat the sewage being generated in the city Lucknow, India. The UASB based STP in Lucknow has a total capacity of 345 MLD and is located in Bharwara, Lucknow and was commissioned under the Gomti Action Plan Phase II. The second STP is FAB based and has a total capacity of 56 MLD. Located in Daulatganj, Lucknow; originally it was commissioned under the Gomti Action Plan Phase I and its capacity was later extended under the Jawaharlal Nehru Urban Renewal Mission. The entire Sewerage network of Lucknow city comprises of 26 major drains which used to directly drain the raw sewage into the Gomti before these STPs came up. Four drains out of these have now been directed to the Daulatganj STP, and the remaining 22 have been proposed to be directed to the Bharwara STP. The Sewerage interconnection work is not yet complete in the city. Figure 1 shows the proposed diversion of the drains to the STPs via several small pumping stations, two intermediate pumping stations and one main pumping station.

In a UASB reactor with three distinct zones- sludge bed, sludge blanket and settling zone, solids get suspended in the blanket and slowly decompose. At the top, solids get separated from the gas and liquid, and biomass rises from sludge bed. Particles in the settling zone settle into the sludge bed after moving through the sludge blanket zone (Hwang and Hansen 1991; Heertjes and Van Der Meer 1978; Lettinga et al 1979; Lettinga et al 1980; Godwin et al 1982). Under favorable physical and chemical conditions, small sludge granules begin to form whose surface area is covered in aggregations of bacteria. Eventually the aggregates form dense compact structures and settle down. On the other hand, the FAB technology is essentially the same as activated sludge except that the media suspended in the reactor offers additional 


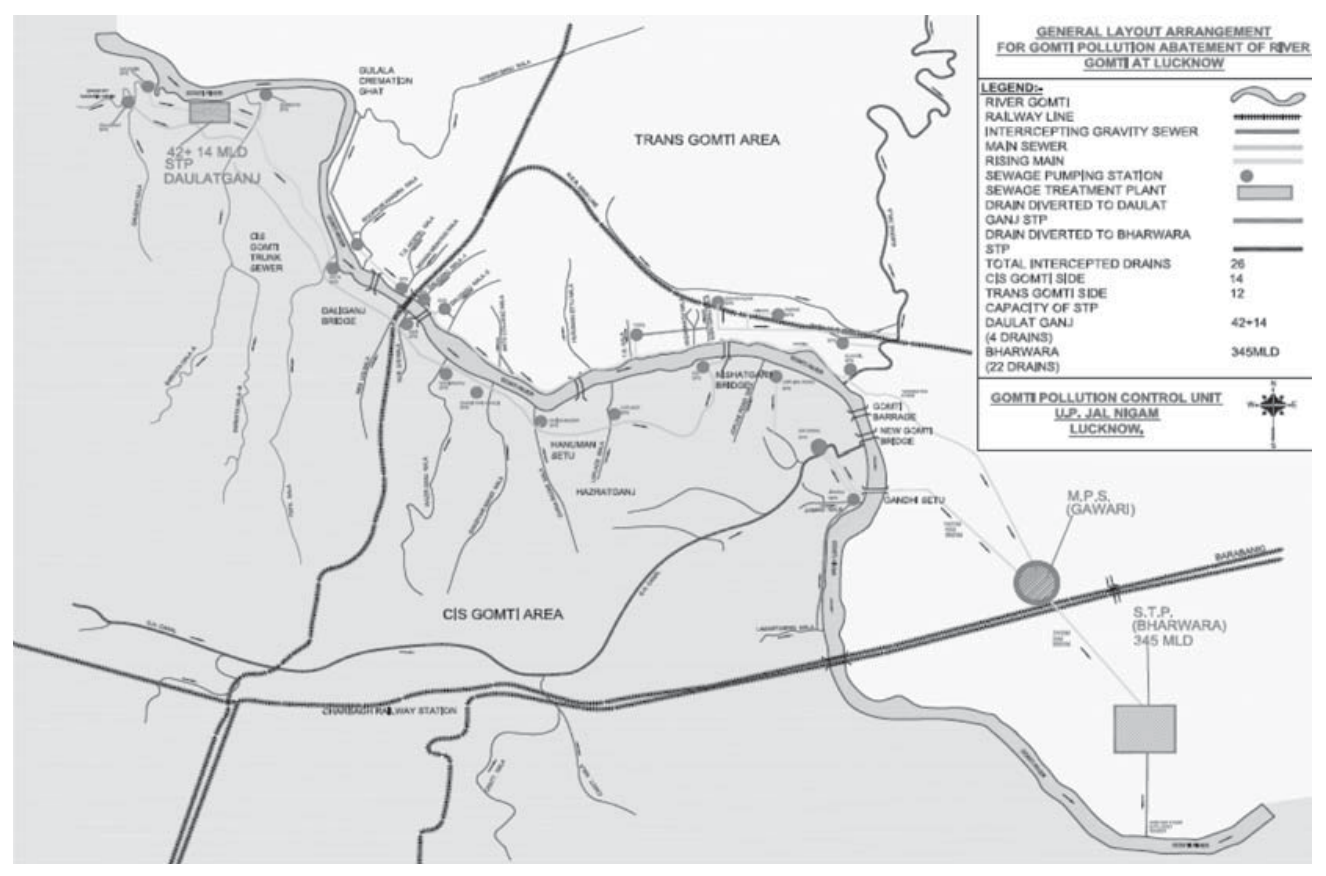

Figure 1. General Layout of Arrangement for Gomti Pollution Abatement at Lucknow. (Courtsey: Gomti Pollution Control Unit, U. P. Jal Nigam, Lucknow) based plant at Bharwara, Lucknow and 56 MLD FAB based treatment at Daulatganj, Lucknow. Observations of the trends of their Life Cycle Costs with varying land cost and treatment capacity have also been reported in this study.

Met hodology for Performance Evaluation Parameters Taken

First of all, water quality parameters namely BOD5 (testing for BOD after taking incubation period surfaces for the microbes to grow and this in turn maximizes the growth of microbes in a given volume of aeration tank compared to the conventional aeration without the media. In FAB technology, the media is kept stationary and is fluidized in the aeration tank. The STP at Daulatganj was initially started as a 42 MLD project in 2002 and later extended to 56 MLD in 2010. The results have been reported for a combined capacity of 56 MLD. The sludge generated in both the cases was dried in sludge drying beds and later dumped as waste or given away to local farmers for free. The treated water in both the cases is discharged into the Gomti River.

While designing a plant, it is tough to decide whether it is efficient to design a single plant that treats a large volume or several plants that treat individual small flows. Thus it is necessary to judge the environmental implications of a sewage treatment plant, considering its capacity. The Life Cycle Analysis (LCA) is a tool used for the evaluation of sewage treatment systems. The LCA weighs the environmental and other potential impacts through the lifetime of a product or service, from the use of raw materials, creating the product, its use and providing it to the customers (Margareta et al 2000; Gallego et al 2008; Hospido et al 2007; Patricia 2011 ).

The main objective of this study is to review and techno-economically compare the performance of the 345 MLD UASB

\begin{tabular}{|c|c|c|c|c|c|c|c|c|}
\hline \multirow{2}{*}{$\begin{array}{l}\text { S. } \\
\text { No. }\end{array}$} & \multirow[b]{2}{*}{ Date } & \multicolumn{3}{|c|}{ Inffluent } & \multirow{2}{*}{$\begin{array}{l}\text { S. } \\
\text { No. }\end{array}$} & \multicolumn{3}{|c|}{ Effluent } \\
\hline & & $\begin{array}{c}\text { TSS } \\
(\mathrm{mg} / \mathrm{l}) \\
\end{array}$ & $\begin{array}{c}\text { BOD } \\
(\mathrm{mg} / \mathrm{l})\end{array}$ & $\begin{array}{l}\text { COD } \\
(\mathrm{mg} / \mathrm{l})\end{array}$ & & \begin{tabular}{|l} 
TSS \\
$(\mathrm{mg} / \mathrm{l})$ \\
\end{tabular} & \begin{tabular}{|l} 
BOD \\
$(\mathrm{mg} / \mathrm{l})$
\end{tabular} & $\begin{array}{l}\text { COD } \\
(\mathrm{mg} / \mathrm{I})\end{array}$ \\
\hline 1. & $1 / 04 / 2012$ & 210 & 104 & 217 & 2. & 20 & 23 & 50 \\
\hline 3. & $2 / 04 / 2012$ & 250 & 108 & 207 & 4. & 20 & 23 & 57 \\
\hline 5. & $3 / 04 / 2012$ & 230 & 116 & 209 & 6. & 30 & 26 & 56 \\
\hline 7. & $4 / 04 / 2012$ & 260 & 110 & 212 & 8. & 30 & 21 & 50 \\
\hline 9. & $5 / 04 / 2012$ & 210 & 100 & 215 & 10. & 20 & 24 & 58 \\
\hline 11. & $6 / 04 / 2012$ & 230 & 118 & 217 & 12. & 20 & 27 & 48 \\
\hline 13. & $7 / 04 / 2012$ & 270 & 102 & 215 & 14. & 30 & 22 & 52 \\
\hline 15. & $8 / 04 / 2012$ & 210 & 110 & 211 & 16. & 20 & 24 & 54 \\
\hline 17. & $9 / 04 / 2012$ & 250 & 116 & 211 & 18. & 20 & 22 & 54 \\
\hline 19. & $10 / 04 / 2012$ & 270 & 108 & 213 & 20. & 30 & 21 & 51 \\
\hline 21. & $11 / 04 / 2012$ & 240 & 118 & 205 & 22. & 20 & 28 & 52 \\
\hline 23. & $12 / 04 / 2012$ & 210 & 100 & 209 & 24. & 20 & 22 & 53 \\
\hline 25. & $13 / 04 / 2012$ & 260 & 126 & 215 & 26. & 30 & 29 & 56 \\
\hline 27. & $14 / 04 / 2012$ & 180 & 104 & 211 & 28. & 20 & 28 & 51 \\
\hline 29. & $15 / 04 / 2012$ & 230 & 114 & 210 & 30. & 20 & 26 & 52 \\
\hline 31. & $16 / 04 / 2012$ & 250 & 124 & 217 & 32. & 30 & 28 & 53 \\
\hline 33. & $17 / 04 / 2012$ & 190 & 100 & 208 & 34. & 20 & 21 & 48 \\
\hline 35. & $18 / 04 / 2012$ & 220 & 110 & 206 & 36. & 20 & 24 & 49 \\
\hline 37. & $19 / 04 / 2012$ & 270 & 118 & 218 & 38. & 20 & 26 & 59 \\
\hline 39. & $10 / 04 / 2012$ & 230 & 102 & 221 & 40. & 20 & 23 & 46 \\
\hline 41. & $21 / 04 / 2012$ & 210 & 102 & 216 & 42. & 30 & 20 & 45 \\
\hline 43. & $22 / 04 / 2012$ & 250 & 118 & 222 & 44. & 30 & 25 & 55 \\
\hline 45. & $23 / 04 / 2012$ & 270 & 124 & 209 & 46. & 30 & 28 & 48 \\
\hline 47. & $24 / 04 / 2012$ & 250 & 114 & 217 & 48. & 20 & 24 & 58 \\
\hline 49. & $25 / 04 / 2012$ & 230 & 111 & 220 & 50. & 20 & 24 & 52 \\
\hline 51. & $26 / 04 / 2012$ & 300 & 115 & 213 & 52. & 30 & 25 & 46 \\
\hline 53. & $27 / 04 / 2012$ & 240 & 100 & 204 & 54. & 20 & 23 & 56 \\
\hline 55. & $28 / 04 / 2012$ & 190 & 124 & 214 & 56. & 20 & 20 & 47 \\
\hline 57. & $29 / 04 / 2012$ & 270 & 113 & 219 & 58. & 30 & 23 & 55 \\
\hline 59. & $30 / 04 / 2012$ & 235 & 107 & 209 & 60. & 24 & 24 & 49 \\
\hline & Mean & 237 & 111 & 213 & & 24 & 24 & 52 \\
\hline
\end{tabular}

Table 2: Results of wastewater quality parameters for the 60 samples collected at Daulatganj STP 


\begin{tabular}{|c|c|c|c|c|c|c|c|c|}
\hline \multirow[b]{2}{*}{ S. No. } & \multirow[b]{2}{*}{ Date } & \multicolumn{3}{|c|}{ Influent } & \multirow[b]{2}{*}{ S. No. } & \multicolumn{3}{|c|}{ Effluent } \\
\hline & & \begin{tabular}{|c|} 
TSS \\
$(\mathrm{mg} / \mathrm{l})$
\end{tabular} & \begin{tabular}{|c|} 
BOD \\
$(\mathrm{mg} / \mathrm{l})$
\end{tabular} & \begin{tabular}{|c|} 
COD \\
$(\mathrm{mg} / \mathrm{l})$
\end{tabular} & & $\begin{array}{c}\text { TSS } \\
(\mathrm{mg} / \mathrm{l})\end{array}$ & \begin{tabular}{|c|} 
BOD \\
$(\mathrm{mg} / \mathrm{l})$
\end{tabular} & $\begin{array}{c}\text { COD } \\
(\mathrm{mg} / \mathrm{l})\end{array}$ \\
\hline 61. & $1 / 04 / 2012$ & 233 & 115 & 209 & 62. & 24 & 25 & 42 \\
\hline 63. & $2 / 04 / 2012$ & 206 & 91 & 213 & 64. & 21 & 21 & 46 \\
\hline 65. & $3 / 04 / 2012$ & 223 & 98 & 203 & 66. & 23 & 22 & 51 \\
\hline 67. & $4 / 04 / 2012$ & 221 & 93 & 205 & 68. & 23 & 22 & 57 \\
\hline 69. & $5 / 04 / 2012$ & 192 & 80 & 199 & 70. & 22 & 24 & 48 \\
\hline 71. & $6 / 04 / 2012$ & 213 & 89 & 207 & 72. & 24 & 20 & 51 \\
\hline 73. & $7 / 04 / 2012$ & 234 & 100 & 209 & 74. & 22 & 23 & 52 \\
\hline 75. & $8 / 04 / 2012$ & 221 & 91 & 203 & 76. & 24 & 19 & 42 \\
\hline 77. & $9 / 04 / 2012$ & 332 & 92 & 208 & 78. & 25 & 26 & 49 \\
\hline 79. & $10 / 04 / 2012$ & 256 & 94 & 207 & 80. & 23 & 22 & 43 \\
\hline 81. & $11 / 04 / 2012$ & 209 & 88 & 202 & 82. & 21 & 21 & 47 \\
\hline 83. & $12 / 04 / 2012$ & 174 & 92 & 211 & 84. & 17 & 23 & 48 \\
\hline 85. & $13 / 04 / 2012$ & 239 & 108 & 200 & 86. & 26 & 22 & 56 \\
\hline 87. & $14 / 04 / 2012$ & 188 & 83 & 210 & 88. & 23 & 23 & 49 \\
\hline 89. & $15 / 04 / 2012$ & 207 & 93 & 204 & 90. & 17 & 22 & 43 \\
\hline 91. & $16 / 04 / 2012$ & 217 & 88 & 200 & 92. & 24 & 24 & 52 \\
\hline 93. & $17 / 04 / 2012$ & 219 & 92 & 205 & 94. & 22 & 21 & 50 \\
\hline 95. & $18 / 04 / 2012$ & 178 & 85 & 212 & 96. & 23 & 20 & 44 \\
\hline 97. & $19 / 04 / 2012$ & 190 & 90 & 213 & 98. & 25 & 22 & 56 \\
\hline 99. & $10 / 04 / 2012$ & 232 & 102 & 208 & 100. & 23 & 25 & 55 \\
\hline 101. & $21 / 04 / 2012$ & 225 & 82 & 200 & 102. & 21 & 23 & 47 \\
\hline 103. & $22 / 04 / 2012$ & 216 & 96 & 212 & 104. & 24 & 22 & 41 \\
\hline 105. & $23 / 04 / 2012$ & 213 & 87 & 206 & 106. & 23 & 20 & 49 \\
\hline 107. & $24 / 04 / 2012$ & 192 & 90 & 199 & 108. & 26 & 21 & 45 \\
\hline 109. & $25 / 04 / 2012$ & 173 & 80 & 201 & 110. & 20 & 18 & 46 \\
\hline 111. & $26 / 04 / 2012$ & 205 & 89 & 201 & 112. & 22 & 19 & 54 \\
\hline 113. & $27 / 04 / 2012$ & 185 & 93 & 212 & 114. & 33 & 22 & 44 \\
\hline 115. & $28 / 04 / 2012$ & 228 & 90 & 204 & 116. & 30 & 20 & 50 \\
\hline 117. & $29 / 04 / 2012$ & 190 & 106 & 206 & 118. & 21 & 24 & 55 \\
\hline \multirow[t]{2}{*}{119.} & $30 / 04 / 2012$ & 176 & 91 & 211 & 120. & 25 & 18 & 53 \\
\hline & Mean & 213 & 92 & 200 & & 23 & 22 & 49 \\
\hline
\end{tabular}

Table 3. Results of wastewater quality parameters for the 60 samples collected at Bharwara STP.

of sample for five days), COD and TSS of the influent and effluent of the two STPs were analyzed under controlled conditions of temperature and $\mathrm{pH}$. Then, the most costeffective and sustainable STP for the city of Lucknow is chosen from the analysis of Life Cycle Cost of STPs in a particular locality based on the above technologies and having the same capacity of treatment but at different land costs. Other results were interpreted in a similar condition but with constant land costs and different capacities. Water quality parameters as considered, BOD5, COD and TSS of the influent and effluent of the two STPs have been tabulated and analyzed in terms of percentage removal. The analytical procedures used have been adopted from Guide Manual: Water and Wastewater Analysis-Central Pollution Control Board, India (Guide Manual 2011).

\section{Data Collection and Sources of Data}

Data of the influent and effluent of each plant were collected and tested for analysis. These tests were conducted in Water Testing Laboratories at the sites of the Sewage Treatment Plants. Overall a number of 120 samples were tested during the pre-monsoon month of April, 2012 in order to minimize chances of dilution of sewage due to rain water which may otherwise affect the actual results. The operating temperature and $\mathrm{pH}$ were controlled between 28$32^{\circ} \mathrm{C}$ and $7 \pm 0.5$ respectively. The primary data were obtained by analysis of samples collected whereas the secondary data was collected from U.P. Jal Nigam, Gomti Pollution Control Unit, Lucknow. Sampling was done in a composite manner and collected samples were refrigerated during the time between collection and analysis. Analysis of the samples was done on the day of collection.

\section{Analysis of Water Quality Parameters}

Three wastewater quality parameters namely; BOD5, COD and TSS of the 120 samples as collected during April, 2012 have been evaluated and given in Table 2 and 3. Percentage removal for all these parameters has been calculated, and shown in Figure 2 and Table 4. Figure 2 shows the comparison in percentage removal efficiency of these two STPs for the considered water quality parameters. From the Table 4 and Figure 2, it can be concluded that:

1. BOD removal efficiency of Daulatganj STP is better than Bharwara STP.

2. COD removal efficiency of Bharwara STP is better than Daulatganj STP.

3. TSS removal efficiency of Daulatganj STP is better than Bharwara STP.

From the above Figure 2 and Table 4, it is clear that in the above condition, to select the best technology with a significant margin on the basis of performance comparison is difficult because BOD and TSS values of Daulatganj STP show greater removal efficiencies while Bharwara STP give greater removal efficiency for COD. However, the difference in removal efficiencies of both the reactors is $\pm 2 \%$, thus these results are not of much use to draw a final conclusion. Hence, the Life Cycle Cost

\begin{tabular}{|c|c|c|c|c|c|c|c|}
\hline \multirow{2}{*}{$\begin{array}{l}\text { S. } \\
\text { No. }\end{array}$} & \multirow{2}{*}{\begin{tabular}{|c|} 
Water \\
Quality \\
Parameter
\end{tabular}} & \multicolumn{3}{|c|}{ Daulatganj STP } & \multicolumn{3}{|c|}{ Bharwara STP } \\
\hline & & $\begin{array}{c}\text { In } \\
\text { flow }\end{array}$ & $\begin{array}{l}\text { Out } \\
\text { flow }\end{array}$ & $\begin{array}{c}\text { \% Rem } \\
\text { oval }\end{array}$ & $\begin{array}{c}\text { In } \\
\text { flow }\end{array}$ & $\begin{array}{c}\text { Out } \\
\text { flow }\end{array}$ & $\begin{array}{l}\text { \%Re } \\
\text { moval }\end{array}$ \\
\hline 1 & $\mathrm{BOD}_{5}(\mathrm{mg} / \mathrm{l})$ & 111 & 24 & 78 & 92 & 22 & 76 \\
\hline 2 & TSS (mg/l) & 237 & 24 & 90 & 213 & 23 & 89 \\
\hline 3 & $\operatorname{COD}(\mathrm{mg} / \mathrm{l})$ & 213 & 52 & 76 & 200 & 49 & 76 \\
\hline
\end{tabular}

Table 4. Treatment Characteristics of Treatment Plants considered under Study. 


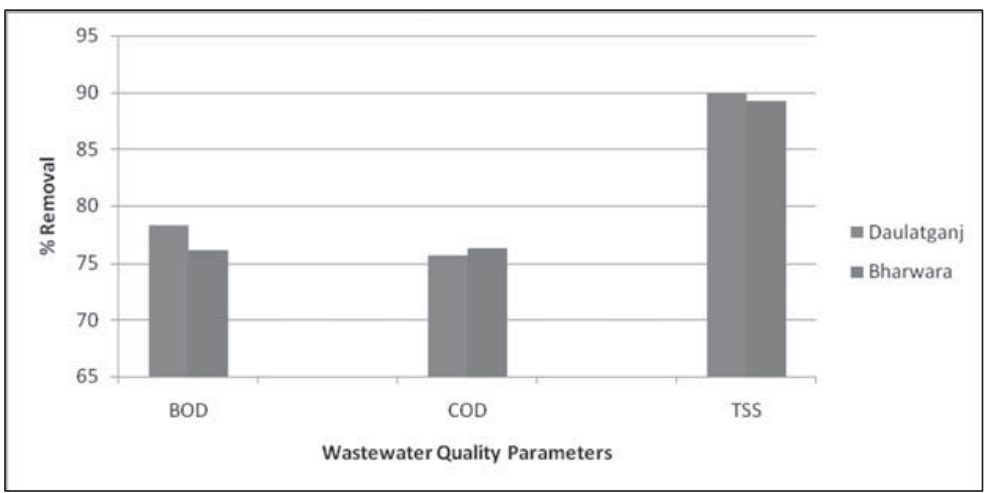

Figure 2. Removal Efficiencies of STPs.

of different technologies used in these STPs has been carried out for selecting the best technology.

\section{Life Cycle Analysis}

Details of Sewage Treatment Plants

The data collected for both the STPs has been summarized in the following Tables 5 and 6.

\begin{tabular}{|c|c|c|c|}
\hline \multirow{2}{*}{$\begin{array}{l}\text { S. } \\
\text { No. }\end{array}$} & \multirow{2}{*}{ Description } & Daulatganj STP & $\begin{array}{c}\text { Bharwara } \\
\text { STP }\end{array}$ \\
\hline & & \multicolumn{2}{|c|}{ Amount (in million Rs. ) } \\
\hline 1 & Staff & 1.37 & 7.34 \\
\hline 2 & O/M Works & 31.48 & 25.40 \\
\hline 3 & $\mathrm{O} / \mathrm{M}$ of Chemicals & 0.36 & 6.72 \\
\hline 4 & Electricity Charges & 36.13 & 15.33 \\
\hline \multirow[t]{2}{*}{5} & Diesel Charges & - & 6.94 \\
\hline & TOTAL & 69.34 & 61.73 \\
\hline \multirow[t]{2}{*}{6} & $\begin{array}{l}\text { Revenue from sale } \\
\text { of sludge }\end{array}$ & 0.72 & 1.80 \\
\hline & NET O/M COST & 68.62 & 59.93 \\
\hline
\end{tabular}

Table 5. Per Annum Cost of Net Operation and Maintenance.

\begin{tabular}{|l|l|l|c|c|}
\hline $\begin{array}{c}\text { S. } \\
\text { No. }\end{array}$ & \multicolumn{1}{|c|}{ Description } & Unit & $\begin{array}{c}\text { Daulatganj } \\
\text { STP }\end{array}$ & $\begin{array}{c}\text { Bhar- } \\
\text { wara } \\
\text { STP }\end{array}$ \\
\hline 1 & Technology & - & FAB & UASB \\
\hline 2 & Capacity & MLD & 56 & 345 \\
\hline 3 & $\begin{array}{l}\text { Construction cost } \\
\text { (exc. land ) }\end{array}$ & Rs. (million) & 223.92 & 1697.10 \\
\hline 4 & Annual Power Cost & Rs. (million) & 36.13 & 22.27 \\
\hline 5 & $\begin{array}{l}\text { Net annual O/M } \\
\text { Cost }\end{array}$ & Rs. (million) & 68.62 & 59.92 \\
\hline 6 & Land required & Ha & 2.02343 & 48.56 \\
\hline 7 & Sludge produced & TPD & 16 & 40 \\
\hline 8 & Biogas generation & $\mathrm{m}^{3} / \mathrm{h}$ & NIL & $\begin{array}{c}\text { Insuf- } \\
\text { ficient }\end{array}$ \\
\hline
\end{tabular}

Table 6. Details of STPs.

\section{Life Cycle Cost}

For calculating, comparing and analyzing the Life Cycle Cost for each of the above mentioned STPs, it is considered that 10 MLD capacity plants based on each of the above mentioned technologies i.e. FAB and UASB are to be constructed, operated and maintained at Lucknow in the same locality to serve the same community. The life of these STPs is assumed to be 20 years (n) and interest rate (i) to be $10 \%$ as prevailing. Life Cycle Costs have been calculated by keeping the capacity of the plant fixed and varying the rate of land. Then Life Cycle Costs have been calculated by varying the size of the plant but keeping the cost of the land constant.

Per MLD annual cost of O\&M is calculated by adding the annual per MLD cost of power and maintenance cost. The total annual O\&M cost is calculated for 10 MLD. Then, the capitalized cost of O\&M for 20 years is calculated by using the following formulas:

- Capitalized O\&M cost for 20 years $=($ Total annual O\&M cost $) \times[\{1-1 /$ $\left.\left.(1+\mathrm{i})^{\wedge} \mathrm{n}\right\} / \mathrm{i}\right]$

- Life Cycle Cost for 20 years= Capital cost including land cost + Capitalized O\&M cost for 20 years.

The potential cost recovery from the sale of sludge has been deducted to calculate the net operation and maintenance cost as shown in Table 5. These cost recovery amounts from sale of sludge generated are approximately Rs. 0.72 million for Daulatganj STP and Rs. 1.8 million for Bharwara STP. Though the recovery amounts are comparatively low still they can be used to compensate a portion of electricity and other bills. It is necessary to deduct the potential cost recovery from the by-products. From the data available at the plants, the following has been deduced:

- Treated effluent is not sold and is discharged into the Gomti river.

- Sludge cakes are taken away by the local farmers for free or are dumped by the Nagar Nigam.

- FAB plant does not produce biogas as it is aerobic.

- UASB plant produces very insignificant amount of biogas as it receives very low organic load.

In Table 7, the Life Cycle costs of the Bharwara and

\begin{tabular}{|c|c|c|c|c|c|c|}
\hline \multirow{2}{*}{$\begin{array}{l}\text { S. } \\
\text { No. }\end{array}$} & \multirow[t]{2}{*}{ Description } & \multirow[t]{2}{*}{ Unit } & \multicolumn{2}{|c|}{$\begin{array}{c}\text { Land rate = } \\
1 \text { million } \mathrm{Rs./} \\
\text { ha }\end{array}$} & \multicolumn{2}{|c|}{$\begin{array}{l}\text { Land rate } \\
=5 \text { million } \\
\text { Rs./ha }\end{array}$} \\
\hline & & & $\begin{array}{c}\text { Daulat } \\
\text { ganj }\end{array}$ & $\begin{array}{l}\text { Bhar } \\
\text { wara }\end{array}$ & $\begin{array}{c}\text { Daulat } \\
\text { ganj }\end{array}$ & $\begin{array}{l}\text { Bhar } \\
\text { wara }\end{array}$ \\
\hline 1 & Design flow & MLD & 10 & 10 & 10 & 10 \\
\hline 2 & $\begin{array}{l}\text { Unit cost of } \\
\text { construction }\end{array}$ & $\begin{array}{l}\text { m i I l i o n } \\
\text { Rs./MLD }\end{array}$ & 4.0 & 4.92 & 4.0 & 4.92 \\
\hline 3 & $\begin{array}{ll}\text { Cost } & \text { of } \\
\text { construction } \\
\text { (except land ) }\end{array}$ & million Rs. & 40.0 & 49.20 & 40.0 & 49.20 \\
\hline 4 & $\begin{array}{l}\text { Unit area } \\
\text { required }\end{array}$ & ha/MLD & 0.04 & 0.14 & 0.04 & 0.14 \\
\hline 5 & Area required & ha & 0.40 & 1.40 & 0.40 & 1.40 \\
\hline 6 & Cost of land & million Rs. & 0.40 & 1.40 & 2.00 & 7.00 \\
\hline 7 & $\begin{array}{l}\text { Total cost of } \\
\text { construction }\end{array}$ & million Rs. & 40.40 & 50.60 & 42.00 & 56.20 \\
\hline 8 & $\begin{array}{l}\text { Unit annual } \\
\text { net O\&M cost }\end{array}$ & $\begin{array}{l}\text { million Rs. } \\
\text { /MLD }\end{array}$ & 1.23 & 0.17 & 1.23 & 0.17 \\
\hline 9 & $\begin{array}{l}\text { Annual cost of } \\
\text { net } O \& M\end{array}$ & million Rs. & 12.30 & 1.70 & 12.30 & 1.70 \\
\hline 10 & $\begin{array}{l}\text { Capitalized } \\
\text { cost of net } \\
\text { O\&M }\end{array}$ & million Rs. & 104.67 & 14.48 & 104.67 & 14.48 \\
\hline 11 & $\begin{array}{l}\text { Cost of STP } \\
\text { for } 20 \text { years }\end{array}$ & million Rs. & 145.07 & 65.08 & 146.67 & 70.68 \\
\hline 12 & $\begin{array}{l}\text { Life Cycle } \\
\text { Cost of STP }\end{array}$ & million Rs. & 145.00 & 65.00 & 147.00 & 71.00 \\
\hline
\end{tabular}

Table 7. Life Cycle Cost Analysis for 10 MLD for Lucknow. 
Daulatganj STPs has been calculated considering a constant STP capacity of 10 MLD for land costs of Rs. 1 million/ha and Rs. 5 million /ha.

In Table 8, the Life Cycle costs of the Bharwara and

\begin{tabular}{|c|c|c|c|c|c|c|}
\hline \multirow{2}{*}{$\begin{array}{l}\text { S. } \\
\text { No. }\end{array}$} & \multirow{2}{*}{ Description } & \multirow{2}{*}{ Unit } & \multicolumn{2}{|c|}{$\begin{array}{c}\text { Land rate }=\mathbf{9} \\
\text { million } \\
\text { Rs./ha }\end{array}$} & \multicolumn{2}{|c|}{$\begin{array}{c}\text { Land rate } \\
=13 \text { million } \\
\text { Rs. } / \text { ha }\end{array}$} \\
\hline & & & $\begin{array}{c}\text { Daulat } \\
\text { ganj }\end{array}$ & $\begin{array}{l}\text { Bhar } \\
\text { wara }\end{array}$ & $\begin{array}{c}\text { Daulat } \\
\text { ganj }\end{array}$ & $\begin{array}{l}\text { Bhar } \\
\text { wara }\end{array}$ \\
\hline 1 & Design flow & MLD & 10 & 10 & 10 & 10 \\
\hline 2 & $\begin{array}{l}\text { Unit cost of } \\
\text { construction }\end{array}$ & $\begin{array}{l}\text { million } \\
\text { Rs. / } \\
\text { MLD }\end{array}$ & 4.00 & 4.92 & 4.00 & 4.92 \\
\hline 3 & \begin{tabular}{|l|} 
Cost of \\
construction \\
(except land)
\end{tabular} & $\begin{array}{l}\text { million } \\
\text { Rs. }\end{array}$ & 40.00 & 49.20 & 40.00 & 49.20 \\
\hline 4 & $\begin{array}{l}\text { Unit area } \\
\text { required }\end{array}$ & ha/MLD & 0.40 & 0.14 & 0.04 & 0.14 \\
\hline 5 & Area required & ha & 0.40 & 1.40 & 0.40 & 1.40 \\
\hline 6 & Cost of land & $\begin{array}{c}\text { million } \\
\text { Rs. }\end{array}$ & 3.60 & 12.60 & 5.20 & 18.20 \\
\hline 7 & $\begin{array}{l}\text { Total cost of } \\
\text { construction }\end{array}$ & $\begin{array}{l}\text { million } \\
\text { Rs. }\end{array}$ & 43.60 & 61.80 & 45.20 & 67.40 \\
\hline 8 & $\begin{array}{l}\text { Unit annual } \\
\text { net O\&M cost }\end{array}$ & $\begin{array}{l}\text { million } \\
\text { Rs. / } \\
\text { MLD }\end{array}$ & 1.23 & 0.17 & 1.23 & 0.17 \\
\hline 9 & $\begin{array}{l}\text { Annual cost of } \\
\text { net } 0 \& M\end{array}$ & $\begin{array}{l}\text { million } \\
\text { Rs. }\end{array}$ & 12.30 & 1.70 & 12.30 & 1.70 \\
\hline 10 & $\begin{array}{l}\text { Capitalized } \\
\text { cost of net } \\
\text { O\&M }\end{array}$ & $\begin{array}{l}\text { million } \\
\text { Rs. }\end{array}$ & 104.67 & 14.47 & 104.67 & 14.47 \\
\hline 11 & $\begin{array}{l}\text { Cost of STP for } \\
20 \text { years }\end{array}$ & $\begin{array}{l}\text { million } \\
\text { Rs. }\end{array}$ & 148.27 & 76.27 & 149.87 & 81.87 \\
\hline 12 & \begin{tabular}{|l|l|l|l} 
Life Cycle \\
Cost of STP
\end{tabular} & $\begin{array}{c}\text { million } \\
\text { Rs. }\end{array}$ & 148.00 & 76.00 & 150.00 & 82.00 \\
\hline
\end{tabular}

Table 8. Life Cycle Cost Analysis for 10 MLD for Lucknow.

\begin{tabular}{|c|c|c|c|c|c|c|}
\hline \multirow{2}{*}{$\begin{array}{l}\text { S. } \\
\text { No. }\end{array}$} & \multirow[b]{2}{*}{ Description } & \multirow[b]{2}{*}{ Unit } & \multicolumn{2}{|c|}{10 MLD } & \multicolumn{2}{|c|}{20 MLD } \\
\hline & & & $\begin{array}{l}\text { Daulat } \\
\text { ganj }\end{array}$ & $\begin{array}{l}\text { Bhar } \\
\text { wara }\end{array}$ & \begin{tabular}{|l|} 
Daulat \\
ganj
\end{tabular} & $\begin{array}{l}\text { Bhar } \\
\text { wara }\end{array}$ \\
\hline 1 & Design flow & MLD & 10 & 10 & 20 & 20 \\
\hline 2 & $\begin{array}{l}\text { Unit cost of } \\
\text { construction }\end{array}$ & \begin{tabular}{c|} 
million \\
Rs./ \\
MLD \\
\end{tabular} & 4.00 & 4.92 & 4.00 & 4.92 \\
\hline 3 & \begin{tabular}{|l} 
Cost of \\
construction \\
(except land )
\end{tabular} & $\begin{array}{l}\text { million } \\
\text { Rs. }\end{array}$ & 40.00 & 49.20 & 80.00 & 98.40 \\
\hline 4 & $\begin{array}{l}\text { Unit area } \\
\text { required }\end{array}$ & ha/MLD & 0.04 & 0.14 & 0.04 & 0.14 \\
\hline 5 & Area required & ha & 0.40 & 1.40 & 0.40 & 1.40 \\
\hline 6 & Cost of land & $\begin{array}{c}\text { million } \\
\text { Rs. }\end{array}$ & 0.40 & 1.40 & 0.80 & 2.80 \\
\hline 7 & $\begin{array}{l}\text { Total cost of } \\
\text { construction }\end{array}$ & $\begin{array}{l}\text { million } \\
\text { Rs. }\end{array}$ & 40.40 & 50.60 & 80.80 & 101.20 \\
\hline 8 & $\begin{array}{l}\text { Unit annual } \\
\text { net O\&M cost }\end{array}$ & \begin{tabular}{|c|} 
million \\
Rs./ \\
MLD \\
\end{tabular} & 1.23 & 0.17 & 1.23 & 0.17 \\
\hline 9 & $\begin{array}{l}\text { Annual cost of } \\
\text { net } O \& M\end{array}$ & $\begin{array}{c}\text { million } \\
\text { Rs. }\end{array}$ & 12.30 & 1.70 & 24.60 & 3.40 \\
\hline 10 & \begin{tabular}{|l|} 
Capitalized \\
cost of net \\
O\&M \\
\end{tabular} & $\begin{array}{l}\text { million } \\
\text { Rs. }\end{array}$ & 104.67 & 14.47 & 209.35 & 28.93 \\
\hline 11 & \begin{tabular}{|l|} 
Cost of STP for \\
20 years
\end{tabular} & $\begin{array}{c}\text { million } \\
\text { Rs. }\end{array}$ & 145.07 & 65.07 & 290.15 & 130.13 \\
\hline 12 & \begin{tabular}{|l|} 
Life Cycle \\
Cost of STP
\end{tabular} & $\begin{array}{c}\text { million } \\
\text { Rs. }\end{array}$ & 145.00 & 65.00 & 290.00 & 130.00 \\
\hline
\end{tabular}

Table 9. Life Cycle Cost Analysis for land cost of 1 million Rs./ ha for Lucknow.
Daulatganj STPs has been calculated considering a constant STP capacity of 10 MLD for land costs of Rs. 9 million/ha and Rs. 13 million/ha.

In Table 9, the Life Cycle costs of the Bharwara and Daulatganj STPs has been calculated considering a constant land cost of 1 million Rs./ha and varying STP capacities of 10 MLD and 20 MLD-

In Table 10, the Life Cycle costs of the Bharwara and Daulatganj STPs has been calculated considering a constant land cost of 1 million Rs./ha and varying STP capacities of 30 MLD and 40 MLD.

PS: 1 Indian Rupee $=0.02$ US $\$$

\section{Results and Discussions}

The LCC of the selected STPs at Lucknow; namely UASB based STP at Bharwara and FAB based STP at Daulatganj has been shown in Tables 7-10. Tables 11-12 and Figure

\begin{tabular}{|c|c|c|c|c|c|c|}
\hline \multirow[b]{2}{*}{$\begin{array}{l}\text { S. } \\
\text { No. }\end{array}$} & \multirow[b]{2}{*}{ Description } & \multirow[b]{2}{*}{ Unit } & \multicolumn{2}{|c|}{30 MLD } & \multicolumn{2}{|c|}{40 MLD } \\
\hline & & & \begin{tabular}{|l|} 
Daulat \\
ganj
\end{tabular} & $\begin{array}{l}\text { B h a r } \\
\text { wara }\end{array}$ & $\begin{array}{l}\text { Daulat } \\
\text { ganj }\end{array}$ & $\begin{array}{l}\text { B h a r } \\
\text { wara }\end{array}$ \\
\hline 1 & Design flow & MLD & 30 & 30 & 40 & 40 \\
\hline 2 & $\mid \begin{array}{ll}\text { Unit cost } & \text { of } \\
\text { construction } & \end{array}$ & \begin{tabular}{|c|} 
million \\
Rs./ \\
MLD
\end{tabular} & 4.00 & 4.92 & 4.00 & 4.92 \\
\hline 3 & $\begin{array}{l}\text { Cost of } \\
\text { construction } \\
\text { (except land) }\end{array}$ & $\begin{array}{c}\text { million } \\
\text { Rs. }\end{array}$ & 120.00 & 147.60 & 160.00 & 196.80 \\
\hline 4 & $\begin{array}{l}\text { Unit } \\
\text { required }\end{array} \quad$ area & ha/MLD & 0.04 & 0.14 & 0.04 & 0.14 \\
\hline 5 & Area required & ha & 1.20 & 4.20 & 1.60 & 5.60 \\
\hline 6 & Cost of land & $\begin{array}{c}\text { million } \\
\text { Rs. }\end{array}$ & 1.20 & 4.20 & 1.60 & 5.60 \\
\hline 7 & $\left|\begin{array}{l}\text { Total cost of } \\
\text { construction }\end{array}\right|$ & $\begin{array}{c}\text { million } \\
\text { Rs. }\end{array}$ & 121.20 & 151.80 & 161.60 & 202.40 \\
\hline 8 & $\begin{array}{l}\text { Unit annual net } \\
\text { O\&M cost }\end{array}$ & $\begin{array}{c}\text { million } \\
\text { Rs./ } \\
\text { MLD }\end{array}$ & 1.23 & 0.17 & 1.23 & 0.17 \\
\hline 9 & $\begin{array}{l}\text { Annual cost of } \\
\text { net O\& M }\end{array}$ & $\begin{array}{l}\text { million } \\
\text { Rs. }\end{array}$ & 36.90 & 5.10 & 49.20 & 6.80 \\
\hline 10 & $\begin{array}{l}\text { Capitalized cost } \\
\text { of net O\&M }\end{array}$ & $\begin{array}{c}\text { million } \\
\text { Rs. }\end{array}$ & 314.02 & 43.40 & 418.69 & 57.87 \\
\hline 11 & $\begin{array}{l}\text { Cost of STP for } \\
20 \text { years }\end{array}$ & $\begin{array}{c}\text { million } \\
\text { Rs. }\end{array}$ & 435.22 & 195.20 & 580.29 & 260.27 \\
\hline 12 & $\begin{array}{l}\text { Life Cycle Cost } \\
\text { of STP }\end{array}$ & $\begin{array}{c}\text { million } \\
\text { Rs. }\end{array}$ & 435.00 & 195.00 & 580.00 & 260.00 \\
\hline
\end{tabular}

Table 10. Life Cycle Cost Analysis for Land Cost of 1 million Rs./ ha for Lucknow.

3-4 show the analysis of the LCC values obtained under two conditions i.e. constant land cost (with varying capacity) and constant capacity (with varying land cost).

Case 1: Life Cycle Cost Analysis of STPs with varying land cost but fixed capacity

The results of Tables 7-8 are summarized as Table 11 and Figure 3, which show the LCC of STPs when both have treatment capacity of 10 MLD but their cost of land is increasing. In this case, the LCC increases for both FAB 
and UASB technologies as the land cost increases but the LCC remains lower for Bharwara STP with UASB technology.

\begin{tabular}{|l|l|c|c|c|c|}
\hline \multicolumn{7}{|c|}{ Varying Land cost (million Rs./ha) } \\
\hline $\begin{array}{c}\text { S. } \\
\text { No. }\end{array}$ & STP Name & $\mathbf{1}$ & $\mathbf{5}$ & $\mathbf{9}$ & $\mathbf{1 3}$ \\
\hline 1 & Daulatganj & 145.00 & 147.00 & 148.00 & 150.00 \\
\hline 2 & Bharwara & 65.00 & 71.00 & 76.00 & 82.00 \\
\hline
\end{tabular}

Table 11. Life Cycle Costs (million Rs.) of STPs with varying Land Cost at Fixed Capacity.

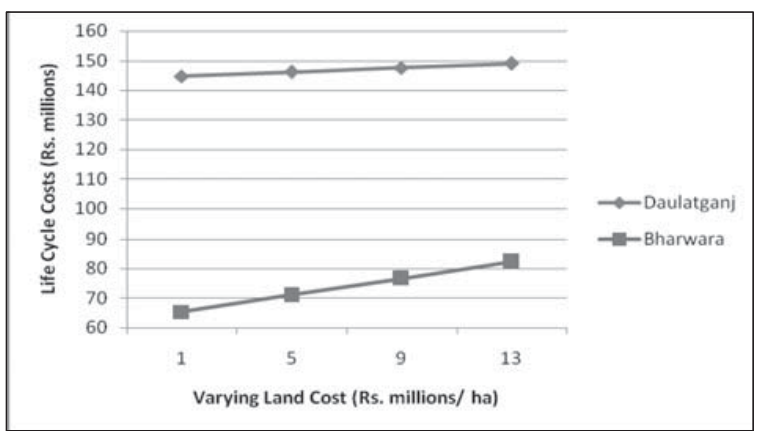

Figure 3. Life Cycle Costs (million Rs.) of STPs with varying Land Cost at Fixed Capacity.

\section{Case 2: Life Cycle Cost Analysis of STPs with} varying capacity but fixed land cost

The results of Tables 9-10 can be summarized as Table 12 and Figure 4, which show the LCC of the two STPs when the cost of land is fixed at 1 million/ha and they are operating at different capacities. Figure 4 shows that the LCC for both STPs increases with the increase in treatment capacity but the LCC of UASB based STP at Bharwara is lower.

\begin{tabular}{|l|l|c|c|c|c|}
\hline \multicolumn{7}{|c|}{ Varying capacity (MLD) } \\
\hline $\begin{array}{c}\text { S. } \\
\text { No. }\end{array}$ & STP Name & $\mathbf{1 0}$ & $\mathbf{2 0}$ & $\mathbf{3 0}$ & $\mathbf{4 0}$ \\
\hline 1 & Daulatganj & 145.00 & 290.00 & 435.00 & 580.00 \\
\hline 2 & Bharwara & 65.00 & 130.00 & 195.00 & 260.00 \\
\hline
\end{tabular}

Table 12. Life Cycle Costs (million Rs.) of STPs with varying Capacity at Fixed Land Cost.

The results of the techno-economical analysis of the two STPs in Lucknow have been summarized in Tables 11-12 and Figures 3-4.

Figure 3 and Figure 4 show that the LCC of Bharwara STP is lower than that of Daulatganj STP in both the cases considered. Other observation from Figure 3 and Figure 4 is that in both the cases the line representing the growth of the LCC for Daulatganj and the line representing the growth of the LCC of Bharwara STP will intersect at a critical point. This critical point represents the critical value of land cost (per hectare) beyond which if the land cost increases, then the Bharwara STP will have a greater LCC than the Daulatganj STP. Similarly, in the second case this critical point represents the critical value of the capacity of STP (MLD) beyond the Bharwara STP will have a greater LCC than the Daulatganj STP.

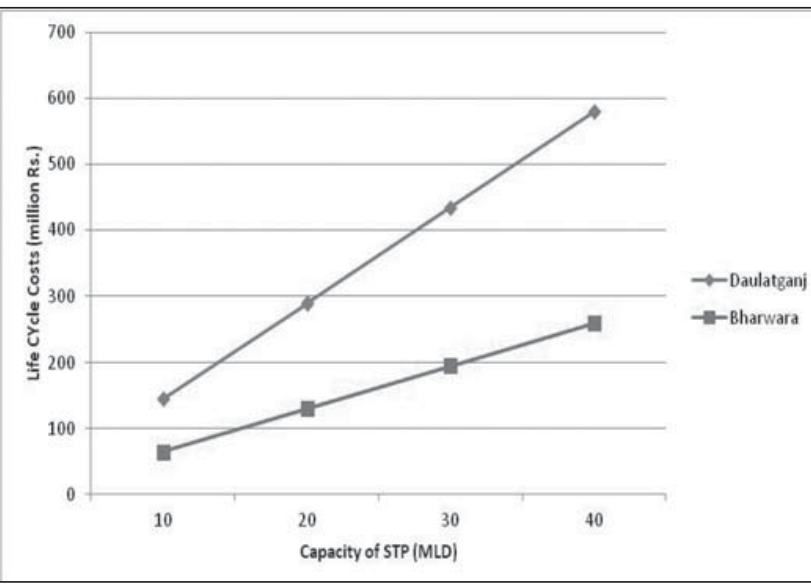

Figure 4. Life Cycle Costs (million Rs.) of STPs with varying Capacity at Fixed Land Cost.

From the above observations, it is clear that in both the cases i.e when the capacity remains constant and when the land cost remains constant, the UASB based STP at Bharwara shows a lower LCC than the FAB based STP at Daulatganj. It is also seen that in both the cases, the rate of increase of the LCC is greater for the Bharwara plant.

\section{Conclusions}

Lucknow city was selected for the study of the performance of two STPs in running condition i.e. the 345 MLD based STP at Bharwara and 56 MLD based STP at Daulatganj. Life Cycle Cost analysis was done for a period of 20 years for the two STPs and the conclusions drawn from the study are as follows:

1. Both of the existing sewage treatment plants are working properly and the results of treated water are observed as per the central pollution control board norms. It has been observed that $100 \%$ of the waste water generated is not treated; thus more plants are required.

2. More foam was observed at site during the visit in the final polishing ponds of the UASB reactor. Antifoaming agents are available in the market to remove the foam, and should be used.

3. Due to the inefficient sewerage network, highly diluted sewage is received at the Bharwara plant due to which there is insignificant biogas generation which could otherwise be used for power generation; hence, cost recovery.

4. All treated water is disposed into the Gomti River. The treated water may be used for industrial and irrigation purposes.

5. Several important Water Quality Parameters like Faecal Coliform, Sulphate, Oil and Grease are not measured on a regular basis.

6. For a particular location i.e. fixed land cost, the LCC of the FAB and UASB reactors increases with the capacity of the STP but the LCC is lower for the UASB reactor up to a particular value of the STP's capacity; however, the rate of increase is greater for 
the UASB reactor.

7. If land the cost increases and the capacity of the STP remains constant, the LCC of both FAB and UASB reactors increases but the LCC is lower for the UASB reactor up to a particular value of the land cost.

8. Due to the low LCC of the UASB based Bharwara STP, it is better for a city like Lucknow.

$$
- \text { - }
$$

Mansi Tripathi, is currently pursuing M.Tech (Environmental Management of Rivers and Lakes) from Alternate Hydro Energy Centre (AHEC), Indian Institute of Technology, Roorkee. She obtained B.Tech degree in Biotechnology from Amity University, Uttar Pradesh, India in 2011. Her research interests are Wastewater Treatment and Management, Conservation of Rivers, Water Pollution Control and Environmental Biotechnology.

Correspondence address: mtrippah@ütrnet.ernet.in

S.K. Singal, BE (Civil, 1983) Roorkee, ME (Earthquake Engineering) University of Roorkee (UoR), Ph D, joined AHEC, UoR in 1984 as scientist. Presently, he is working as Senior Scientific Officer in AHEC. He has research and teaching experience of more than 28 years in the field of Small Hydropower. He has guided 30 M. Tech. Theses, contributed 100 research papers in International and national journals and conferences. He has organized more than 30 short term training courses on different aspects of small hydropower and water resources, and has delivered expert lectures in more than 100 training program for international and national in service engineers.

Correspondence address: sunilksingal@gmail.com

\section{References}

ADF Health Manual, 2012, Vol. 20, part8, chp2, http://www.defence.gov.au/jlc/Documents/DSCC/ ADF\%20Health\%2oManual\%20Vol\%2020,\%20 part8,\%2ochp2.pdf. Accessed on 14 September, 2012.

Central Public Health and Environmental Engineering Organisation, 2012, Manual on sewerage and sewage treatment, Ministry of urban development, New Delhi, 1993, http://www.indiawaterportal.org/ node/12573, accessed on 15 September, 2012.

Chavan, A. D., 2007, Performance evaluation of existing STPs for Nasik city, M.Tech Project Report, AHEC, IIT-Roorkee.

Gallego, A., A. Hospido, M.T. Moreira, and G. Feijoo, 2008, Environmental performance of wastewater treatment plants for small populations, Resources, Conservations and Recycling, 52(6), pp. 931-940.

Geo Miller \& Co. Pvt., 2010, Operation and Maintenance manual for 14 MLD STP based on FAB Technology at Daulatganj, Lucknow.
Godwin, S. J., D.A.J. Wase and C. F. Forster, 1982, Use of upflow anaerobic sludge blanket reactor to treat acetate rich water, Process Biochemistry, 13, 33-45.

Guide Manual: Water and Wastewater AnalysisCentral Pollution Control Board, 2011, http:// www.cpcb.nic.in/upload/Latest/Latest_67_ guidemanualw\&wwanalysis.pdf accessed on 28 March, 2012.

Patricia, Güereca Leonor, 2011, A comparative life cycle assessment of a wastewater treatment technology considering two inflow scales, Life Cycle Management Conference-2011, The Dahlem Cube, Berlin, August 28-31, 2011.

Heertjes, P. M. and R.R Van Der Meer, 1978, Dynamics of liquid flow in an up-flow reactor used for anaerobic treatment of wastewater, Biotechnology and Bioengineering, 20(10), pp.1577-94.

Hospido, A., M.T. Moreira and G. Feijoo, 2007, A comparison of municipal wastewater treatment plants for big centres of population in Galicia (Spain), International Journal of Life Cycle Assessment, 13(1), pp57-64.

Jamwal, P., A. K. Mittal and J.M. Mouchel, 2009, Efficiency evaluation of sewage treatment plants with different technologies in Delhi, Environmental Monitoring Assessment, 153, pp. 293-305.

Lettinga, G., A. Th. Van Der Geest, S. Homa and J.V.D. Laan, 1979, Anaerobic treatment of methanolic wastes, Water Research, 13(8), 725-37.

Lettinga, G., A. F. M. Van Velsen, S. W. Hobma, W. De Zeeuw and A. Kalpwijk, 1980 Use of the upflow sludge blanket (USB) reactor concept for biological wastewater treatment, especially for anaerobic treatment, Biotechnology and Bioengineering, 22(4), pp. 699-734.

Lundin, M., M. Bengtsson and S. Molander, 2000, Life cycle assessment of wastewater systems: influence of system boundaries and scale on calculated environmental loads, Environmental Science and Technology, 34(1), pp. 180-186.

Metcalf and Eddy, 2003, Wastewater Engineering, Mc Graw Hill Inc, $3^{\text {rd }}$ edition, pp.1005-1016.

Naturgerechte Technologien, 2012, Bau-und Wirtschaftsberatung, Anaerobic treatment of municipal wastewater in UASB-reactors, http:// www. gate-international.org/documents/ techbriefs/ webdocs/pdfs/w6e_2001.pdf accessed on 20 September, 2012.

Nigam, U. P. Jal, April, 2012, Performance report of 14 MLD STP, Daulatganj.

Nigam, U. P. Jal, April, 2012, Performance report of 345 MLD STP, Bharwara.

Nigam, U. P. Jal, March, 2012, Proforma for reporting physical/financial progress each month Gomti Action Plan Phase-1.

Soni, S., 2009, Operation strategy for STPs at Varanasi, M.Tech Project Report, AHEC, IIT- Roorkee. 